\title{
DUKUNGAN KELUARGA DAN MODAL PSIKOLOGIS MAHASISWA
}

\author{
Unika Prihatsanti \\ Fakultas Psikologi Universitas Diponegoro \\ J1. Prof Sudharto SH, Tembalang, Semarang 50274 \\ unika_prihatsanti@undip.ac.id
}

\begin{abstract}
Psychological capital in students is a positive psychological condition that enables students to deal with uncomfortable situation so that they could finish their study in college and prepare themselves to enter professional world. This study aims to test the correlation between family support and psychological capital in college students. In total, 126 students joined the study. Data were collected using the Family Support Scale (21 items; $\alpha=0.892)$ and the Psychological Capital Scale (20 items; $\alpha=0.892)$. Data analysis using simple regression analysis revealed a positive significant correlation between family support and psychological capital $(r=0.215 ; p=0.008)$
\end{abstract}

Keywords: family support, psychological capital, college students

\begin{abstract}
Abstrak
Modal psikologis mahasiswa merupakan kondisi psikologis positif yang memampukan mahasiswa untuk menghadapi kondisi tidak menyenangkan sehingga mereka mampu menyelesaikan studi dan mempersiapkan diri secara maksimal untuk masuk dunia kerja. Penelitian ini bertujuan untuk menguji hubungan dukungan keluarga dan modal psikologis mahasiswa. Sebanyak 126 mahasiswa menjadi responden dalam penelitian ini. Data dikumpulkan menggunakan 21 item Skala Dukungan Keluarga $(\alpha=0,892)$, dan 20 item Skala Modal Psikologis $(\alpha=0,892)$. Analisis data menggunakan analisis regresi sederhana yang menunjukkan dukungan keluarga berkorelasi positif dan dengan modal psikologis mahasiswa $(r=0,215 ; p=0,008)$
\end{abstract}

Kata Kunci: dukungan keluarga, modal psikologis, mahasiswa

\section{PENDAHULUAN}

Lingkungan perguruan tinggi merupakan salah satu lingkungan yang dapat menimbulkan stress tersendiri bagi mahasiswa (Yu Wen \& Chuan Lin, 2014). Hasil observasi dan interviu di lapangan menunjukkan bahwa sampai pada tahap penyelesaian skripsi, mahasiswa memiliki kendala dalam menemukan judul, kesulitan menemui dosen pembimbing, merasa bahwa dosen pembimbing hanya sebagai 'tukang coret' ketika melakukan pembimbingan, sulit menuliskan isi skripsi yang membuat mahasiswa akhirnya tidak memiliki motivasi untuk menyelesaikan skripsi mereka secepat mungkin. Pada mahasiswa semester lebih awal ditemukan bahwa banyak tugas yang tidak terselesaikan dengan maksimal atau lewat dari batas waktu pengumpulan, tidak mengerjakan tugas, menunda pekerjaan, kurang mengikuti proses perkuliahan, keterlambatan kehadiran, komunikasi dosen dan mahasiswa yang kurang lancar serta mengakibatkan terganggunya proses belajar. Mahasiswa seringkali terbebani dalam proses perkuliahan dengan tugas yang banyak, dosen sering memberikan tugas apalagi ketika sks yang diambil banyak maka tugaspun akan semakin banyak, kurangnya waktu dalam ikut kegiatan atau organisasi di kampus dengan alasan tugas atau kuliah. Sulit menemukan 
referensi yang 'pas', banyaknya keluhan mahasiswa saat dosen memberikan referensi dalam bahasa Inggris.

Berdasarkan diskusi dengan beberapa dosen ditemukan bahwa sebagian besar mahasiswa kurang memiliki keinginan untuk belajar secara mandiri dan hanya menunggu instruksi dosen. Pengalaman peneliti sebagai dosen pembimbing akademik (dosen wali) menemukan bahwa mahasiswa seringkali menhadapi tuntutan keluarga untuk segera menyelesaikan studi; tidak jarang orang tua menjadi marah ketika anaknya (mahasiswa) mendapatkan indeks prestasi (IPK) kurang dari 3,0 atau masa studi yang lebih dari 4 tahun. Kondisi tersebut menimbulkan tekanan tersendiri bagi mahasiswa. Tampaknya mahasiswa memerlukan suatu kondisi psikologis positif yang tidak hanya menyangkut kemampuan intelektual dan kemampuan berkompetisinya di kampus dan dunia kerja nantinya, namun untuk dapat tetap bertahan selama proses kuliah, menyelesaikan tugas-tugas perkuliahan tepat waktu dengan kualitas baik, serta tuntutan sosial lainnya. Kondisi psikologis positif inilah yang disebut Luthans sebagai modal psikologis (Luthans, Youssef dan Avolio, 2007).

Modal psikologis diartikan sebagai keadaan psikologi individu yang positif, yang dicirikan oleh: (1) adanya keyakinan diri atau efikasi diri dalam melakukan tindakan yang perlu untuk mencapai sukses dalam tugas-tugas yang menantang (selfefficacy); (2) atribusi yang positif (optimisme) tentang sukses masa sekarang dan yang akan datang; (3) persistensi dalam mencapai tujuan , dengan kemampuan mendefinisikan kembali jalur untuk mencapai tujuan jika diperlukan demi mencapai kesuksesan (hope); dan (4) ketika menghadapi masalah dan kesulitan, individu mampu bertahan dan terus maju (resiliency) untuk mencapai sukses
(Luthans,Avolio, Avey, dan Norman, 2007).

Penelitian menunjukkan hasil bahwa modal psikologis mampu mengurangi stress di berbagai disiplin ilmu (Rioli, Savicki, \& Richards, 2012; Yu Wen \& Chuan Lin,2014). Hossein, Manijeh dan Pasha (2014) menambahkan bahwa empat dimensi modal psikologis, yaitu efikasi, optimism, harapan dan resiliensi memberikan pengaruh secara signifikan pada performa akademik mahasiswa. Maka menjadi penting jika modal psikologis mendapatkan perhatian untuk dapat meningkatkan performa mahasiswa, meningkatkan indeks prestasi, memberikan jalan bagi mahasiswa untuk mencapai tujuan mereka, secara realistis, optimis, memberi keyakinan untuk melakukan perubahan positif di tempat kuliah, lingkungan dan bangkit kembali jika mengalami kegagalan.

Banyak penelitian telah dilakukan untuk meneliti modal psikologis dalam konteks organisasi. Avey (2014) menyatakan sejak tahun 2005 telah ada puluhan studi dengan modal psikologis yang memprediksi kinerja individu yang optimal (misalnya: organizational citizenship behavior, perilaku menyimpang), dan sikap (misalnya, kepuasan, komitmen, kesejahteraan, keinginan berpindah). Di Indonesia Tjakraatmadja (2009) telah meneliti hubungan antara psychological capital, lingkungan belajar sebagai faktor eksternal (variabel moderator) dan nilai IPK mahasiswa (sebagai indikator kinerja). Lebih lanjut Tjakraatmadja menjelaskan pengaruh nilai SPMB dan psikotest terhadap indeks prestasi (IPK) mahasiswa yang dipengaruhi oleh psychological capital dan lingkungan belajar mahasiswa ITB. Hasil penelitian menunjukkan bahwa psychological capital memiliki hubungan pengaruh positif yang signifikan terhadap indeks prestasi mahasiswa. Namun, masih 
sedikit kajian mengenai faktor-faktor yang berpengaruh pada modal psikologis. Qadeer \& Jaffery (2014) menemukan bahwa iklim organisasi merupakan salah satu faktor yang mempengaruhi modal psikologis karyawan. Belum ditemukan penelitian mengenai faktor yang mempengaruhi modal psikologis dalam konteks akademis, Peneliti menduga dukungan keluarga merupakan salah satu faktor yang berkaitan dengan modal psikologis.

Canavan dan Dolan (2006) menjelaskan bahwa dukungan keluarga merupakan salah satu bentuk dukungan sosial informal antara anggota keluarga, dan dapat disebut sebagai central helping system. Terdapat empat tipe dukungan di dalam keluarga menurut Cutrona (dalam Canavan \& Dolan, 2006) yaitu (1) dukungan konkret,; dukungan yang berkaitan dengan tindakan langsung pada kegiatan sehari-hari; (2) dukungan emosional, yaitu empati, mendengarkan, dan keberadaan ketika seseorang mengalami permasalahan; (3) dukungan nasihat, yang sebenarnya lebih kompleks dalam penjelasannya karena biasanya yang lebih dibutuhkan individu adalah rasa nyaman dalam berbagi dan menerima masukan, ketimbang isi dari nasihat itu sendiri; (4) dukungan penghargaan, berfokus pada bagaimana seseorang dimaknai keberadaannya. Dukungan keluarga memiliki peran penting diantaranya adalah sebagai penanaman kekuatan dan mengurangi risiko gangguan kesehatan mental anggota didalamnya, merupakan tempat teraman dan ternyaman bagi anggotanya, juga sebagai titik penting bagi perkembangan individu (Canavan, Dolan, \& John, 2000)

\section{METODE}

Subjek penelitian adalah 126 mahasiswa S1 Fakultas Psikologi angkatan 2009-2011, yang ditentukan dengan teknik convenience sampling. Modal psikologis diungkap menggunakan skala modal psikologis yang disusun oleh peneliti berdasarkan empat dimensi yang dikemukakan oleh Luthans, Youseff \& Avolio (2007). Skala terdiri dari 20 item valid $(\alpha=0,892)$ dengan variasi pilihan jawaban 1 (sangat tidak sesuai) sampai 6 (sangat sesuai). Semakin tinggi skor menunjukkan semakin tinggi modal psikologis yang dimiliki oleh mahasiswa. Dukungan keluarga diungkap menggunakan Skala Dukungan Keluarga yang disusun oleh peneliti menggunakan tipe dukungan keluarga menurut Cutrona (dalam Canavan dan Dolan, 2006). Skala terdiri dari 21 item valid $(\alpha=0,892)$ dengan variasi pilihan jawaban 1 (sangat tidak sesuai) sampai 6 (sangat tidak sesuai). Semakin tinggi skor berarti semakin tinggi pula dukungan keluarga. Analisis data dilakukan dengan teknik analisis regresi sederhana.

\section{HASIL DAN PEMBAHASAN}

Hasil analisis data menunjukkan adanya korelasi positif yang signifikan antara dukungan sosial dan modal psikologis mahasiswa $(r=0,215 ; p=0,008)$. Hasi ini menunjukkan bahwa dukungan keluarga memegang peranan pada munculnya modal psikologis pada mahasiswa.

Modal psikologis merupakan karakteristik psikologis positif yang tersusun atas empat dimensi, yaitu self efikasi, harapan, optimism dan resiliensi. Luthans (2007) menjelaskan keempat dimensi ini saling berinteraksi dan berhubungan dengan yang lainnya. Bahwa modal psikologis ini merupakan kapasitas positif individu yang terbarukan, saling melengkapi dan bersinergi. 
Kondisi yang dihadapi oleh mahasiswa dengan banyak tuntutan yang berkaitan dengan tugas akademik, yang menyebabkan tekanan tersendiri. Tekanan atau stressor tidak hanya berasal dari tugas akademik tetapi juga tantangan dalam menjalin relasi dengan lingkungan di sekitarnya. Adlaf, dkk (Riolli, Savicki \& Richards, 2012) menyatakan bahwa stress paling besar ditemukan pada lingkungan akademik. Penelitian Riolli, Savicki \& Richards (2012) menemukan bahwa untuk mengatasi kondisi tersebut diperlukan modal psikologis.

Modal psikologis berdasarkan penelitian menunjukkan sebanyak 74,60\% (94 orang dari 126 mahasiswa) berada pada kategori tinggi dan 25,40\% (32 orang dari 126 mahasiswa) berada pada kategori sedang. Mahasiswa yang memiliki modal psikologis akan mampu menghadapi situasi stress seperti menghadapi ujian akhir, dan akan meningkatkan kesejahteraan psikologis mereka (Riolli, Savicki, Richard, 2012). Mahasiswa menjadi lebih aktif dalam menetapkan tujuan yang ingin dicapai ketika memiliki efikasi diri tinggi sehingga memiliki prestasi akademik yang tinggi. Sebaliknya efikasi diri rendah akan membuat mahasiswa mudah putus asa dan tidak yakin akan kemampuan mereka dalam menyelesaikan tugas. Bisa jadi mahasiswa dengan self efikasi rendah akan bekerja dibawah kemampuan mereka yang sebenarnya. Bandura dan Locke (Luthans, Youssef dan Avolio 2007) menjelaskan bahwa efikasi diri memungkinkan individu untuk menetapkan tujuan, mengatur motivasi, tindakan, serta mengontrol proses belajar mereka. Individu yang memiliki efikasi diri (self efficacy) meyakini kemampuan yang mereka miliki. Ketika mahasiswa memiliki harapan (hope) artinya bahwa mereka memiliki kemampuan dalam menemukan cara untuk mencapai tujuan yang diharapkan dan termotivasi untuk menempuh usaha tersebut (Syder dan Lopes, 2002). Individu akan mengekspresikan dengan mengerjakan tugas dengan baik, cenderung bekerja dengan cara yang berbeda (Luthans, 2007).

Berdasarkan analisis data tingginya modal psikologis mahasiswa ini tidak lepas dari peran dukungan keluarga. Dukungan keluarga ini dapat berupa saran, dan nasihat. Selain itu bentuk dukungan keluarga lainnya adalah pujian, penghargaan, penilaian, bantuan peralatan dan keuangan (House dan Kahn dalam Widanarti dan Indati, 2002).

Tabel 1 menunjukkan hubungan dukungan keluarga dan modal psikologis:

Tabel 1. Korelasi antara Aspek-aspek Dukungan Keluarga dengan Modal Psikologis Mahasiswa

\begin{tabular}{llc}
\hline Aspek Dukungan & \multicolumn{2}{c}{ Modal Psikologis } \\
\cline { 2 - 3 } Keluarga & $\boldsymbol{r}$ & $\boldsymbol{p}$ \\
\hline Dukungan emosional & 0,167 & $0,030^{*}$ \\
Dukungan & 0,255 & $0,002^{* *}$ \\
penghargaan & & \\
Dukungan nasihat & 0,285 & $0,001^{* *}$ \\
Dukungan konkrit & 0,045 & 0,307 \\
\hline Catatan: ${ }^{*} p<0,05 ; * * p<0,01$ & \multicolumn{2}{c}{}
\end{tabular}

Seperti yang ditampilkan dalam Tabel 1, tampak adanya hubungan yang signifikan antara aspek-aspek dukungan keluarga dengan modal psikologis mahasiswa. Pertama, dalam hal dukungan emosional. Hal ini salah satunya bisa dilakukan oleh keluarga. Mahasiswa yang menjadi subjek penelitian adalah mahasiswa Psikologi angkatan 2009-2011 dengan rentang usia 17-19 tahun, yang merupakan tahap perkembangan remaja menurut WHO. Menurut WHO remaja merupakan masa transisi dari kanak-kanak menuju dewasa dengan batasan usia 12-24 tahun, sedangkan menurut Menteri Kesehatan RI tahun 2010 batasan usia remaja adalah 1019 tahun dan belum menikah. Remaja pada usia ini seharusnya sudah mampu mandiri 
baik secara ekonomi maupun emosional (Havighurst dalam Monk dkk, 1998). Namun kenyataannya di Indonesia sebagian besar remaja dalam hal ini adalah mahasiswa masih terikat dengan keberadaan keluarga baik secara ekonomi maupun emosional. Keluarga merupakan lingkungan terdekat yang membentuk ikatan khusus yang dapat menghindarkan mereka dari rasa takut, cemas ketika menghadapi kegagalan dalam tugas akademik

Kedua, dukungan penghargaan; dukungan ini berupa perasaan dipercaya, penerimaan dan perhatian yang dapat memotivasi mahasiswa untuk membantu keberhasilan yang berkaitan dengan tugas-tugas akademik. Menurut Hurlock (1980), dukungan penghargaan dapat meningkatkan kebahagiaan yang pada akhirnya mendorong keberhasilan seseorang dalam menyelesaikan tugasnya. Perasaan sukses akan meningkatkan keyakinan diri seseorang sedangkan ketiadaan dukungan memunculkan perasaan gagal dan tidak yakin. Sejalan dengan penelitian Widanarti dan Indati (2002) yang menemukan hubungan dukungan keluarga dengan self efikasi.

Ketiga, dukungan nasihat memberikan kontribusi pada modal psikologis mahasiswa. Menurut Bandura (1986) individu yang diberikan nasihat, saran, bimbingan akan lebih mampu meningkatkan kemampuannya sehingga dapat mencapai tujuan yang diharapkan sehingga mampu mendorong seseorang untuk menunjukkan prestasi terbaiknya.

Dukungan kongkrit menunjukkan hubungan yang tidak signifikan, yang berarti bahwa dukungan ini tidak memberikan kontribusi pada modal psikologis mahasiswa. Berdasarkan wawancara dukungan kongkrit kurang dirasakan oleh mahasiswa terutama berkaitan dengan pengerjaan tugas-tugas kuliah maupun penyelesaian skripsi secara langsung.

\section{KESIMPULAN}

Berdasarkan hasil penelitian dapat ditarik kesimpulan bahwa terdapat hubungan positif yang signifikan antara dukungan keluarga dan modal psikologis pada mahasiswa $(r=0,215 ; p=0,008)$. Semakin tinggi dukunga keluarga maka akan semakin tinggi modal psikologis mahasiswa demikian pula sebaliknya semakin rendah dukungan keluarga maka akan semakin rendah modal psikologis mahasiswa. Penelitian ini memiliki keterbatasan dan dapat dijadikan sebagai bahan kajian bagi peneliti selanjutnya, yaitu kurangnya identifikasi terhadap jenis kelamin dan usia subjek penelitian yang diprediksikan turut mempengaruhi tinggi rendahnya modal psikologis mahasiswa.

\section{DAFTAR PUSTAKA}

Avey, J. B. (2014). The left side of psychological capital new evidence on the antecedents of psycap. Journal of Leadership \& Organizational Studies. 21 (2): 141149

doi: $10.1177 / 1548051813515516$.

Bandura, A. (1986). A social cognitive theory: Social foundation of thought and action. New Jersey: Prentice Hall, Inc.

Dolan, P. \& Canavan, J. (2006). Family support as reflective practice. London: Jessica Kingsley Publishers.

Dolan, P., Canavan, J., \& Pinkerton, J. (2000). Family support direction 
from diversity. London: Jessica Kingsley Publishers.

Hossein, M. N. M., Manijeh, S., \& Pasha, S. H. (2014). The relationship of psychological capital (hope, resiliency and self-efficacy) with the achievement goals and academic performance og the first-year student. Curriculum planning knowledge \& research in educational sciences, 11(12): 61-79.

Hurlock. E. B. (1980). Psikologi Perkembangan,Suatu Pendekatan Sepanjang Rentang Kehidupan. Jakarta: Airlangga.

Mönks, F. J., Knoers, A. M. P., \& Haditono, S. R. (1998). Psikologi perkembangan. Yogyakarta: Gadjah Mada University Press.

Luthans, F., Youssef, C. M., Avolio, B. J. (2007). Psychological capital:

Developing the human competitive edge. New York: Oxford University Press.

Luthans, F., Avolio, B. J, Avey, J. B, \& Norman, S. M. (2007). Positive psychological capital: Measurement and relationship with performance and satisfaction. Personal Psychology, 60: 541-572.

Qadeer, F. \& Jaffery, H. (2014). Mediation of psychological capital between organizational climate and organizational citizenship behavior. Pakistan Journal of Commerce and Social Sciences, 8(2), 453-470.
Riolli, L, Savicki, V, \& Richards, J. Psychological capital as a buffer to student stress. Psychology 2012. 3 (12A):1202-1207. http://dx.doi.org/10.4236/psych.2012 .312A178

Shein, J. \& Chen, C. P. (2010). Workfamily enrichment: A research of positive transfer. Toronto: University of Toronto.

Tjakraatmaja, JH. (2009). Apakah indeks prestasi mahasiswa ITB dapat digunakan untuk memprediksi kinerja mereka pada saat bekerja nanti. Berita Pembelajaran. No. 4 tahun 2.

Yu Wen, M.L, Chuan Lin, D.Y. (2014). Does Psychological Capital Combat Learning and Adaptive Stress of College Freshmen. Journal of studies in Education; ISSN (Online): 21626952, 4(1): 25-42.

Widanarti, N., Indati, A. (2002). Hubungan antara dukungan sosial keluarga dengan self efficacy pada remaja di SMU Negeri 9 Yogyakarta. Jurnal Psikologi, 2, 112-123. 